\title{
Upaya Meningkatkan Kemampuan Sosial Emosional Melalui Metode Proyek Usia 5-6 Tahun Di Tk.Nurussyakirin Sindang Jaya Kabupaten Tangerang
}

\author{
Sopiah 1, Evy Fitria ${ }^{2}$ \\ 1,2 Program Studi Pendidikan Guru Pendidikan Anak Usia Dini, Fakultas \\ Keguruan Dan Ilmu Pendidikan, Universitas Muhammadiyah Tangerang. \\ Email: ${ }^{1}$ sopiaharsyad1992@gmail.com, ${ }^{2}$ evifitria7@gmail.com
}

\begin{abstract}
ABSTRAK
Kemampuan sosial emosional anak di TK. Nurussyakirin masih tergolong rendah, ada 9 anak yang masih rendah kemampuan sosial emosionalnya hal ini disebabkan oleh beberapa faktor diantaranya kurang nya bekerjasama dengan teman sebaya, belum mampu sabar menunggu giliran, kurang mematuhi peraturan, dan belum mampu mengendalikan emosi. Penelitian ini bertujuan untuk mengembangkan Sosial Emosional anak melalui metode proyek di Tk.Nurussyakirin Sindang Jaya Kabupaten Tangerang. Penelitian ini menggunakan metode penelitian tindakan kelas (PTK). Hal ini terlihat dari adanya peningkatan kemampuan sosial emosional anak pada pembahasan siklus 1, siklus II dan siklus III, anak didik yang berkembang sangat baik/BSB pada siklus I 8\% sedangkan pada siklus II meningkat sebesar 50\% dan pada siklus III meningkat sebesar $100 \%$. Berdasarkan hasil analisis data dan pembahasan maka dapat penulis simpulkan bahwa metode proyek dapat meningkatkan kemampuan sosial emosional anak pada kelompok B di TK.Nurussyakirin Sindang Jaya Kabupaten Tangerang.
\end{abstract}

Kata kunci : Usia 5-6 tahun, sosial emosional, Metode proyek

\section{Pengantar}

Menurut Hurlock dalam Susanto (2011.h.131) secara luas diketahui bahwa periode anak terbagi menjadi dua peroide yaitu masa anak -anak awal dan masa anak-anak akhir.masa anak- anak akhir,yaitu dimulai dari, masa Anak usia dini adalah salah satu periode yang sangat penting, karena periode ini merupakan tahap perkembangan kritis dan masa keemasan. Pada masa inilah kepribadian seseorang mulai dibentuk. pengalamam-pengalaman dimasa ini cenderung bertahan dan mempengaruhi sikap anak sepanjang hidupnya, untuk 


\section{"Ceria"}

Jurnal Pendidikan Anak Usia Dini

ISSN 2301-9905

Volume 9, No.2, Januari 2019

Fakultas Keguruan dan Ilmu Pendidikan- Universitas Muhammadiyah Tangerang

meningkatkan pertumbuhan dan perkembangan anak usia dini para praktisi pendidikan menyelenggarakan PAUD (pendidikan anak usia dini).

Pendidikan anak usia dini merupakan salah satu lembaga pendidikan prasekolah yang di harapkan dapat menjadi fasilitator bagi perkembangan anak. Pendidikan anak usia dini (PAUD) merupakan lembaga yang membina, mengasuh, dan mengembangkan pertumbuhan dan perkembangan anak usia dini,serta merupakan strategi pembangunan sumber daya manusia.

Pendidikan anak usia dini (PAUD) merupakan wadah dimana anak usia 0-6 tahun yang diberikan rangsangan dan stimulasi untuk meningkatkan pertumbuhan dan perkembangan sesuai dengan tahapan perkembangannya. Pendidikan anak usia dini diselenggarakan dengan tujuan untuk memfasilitasi pertumbuhan dan perkembangan anak secara menyeluruh, karena usia dini merupakan fase yang fundamental dalam mempengaruhi perkembangan anak. Sesuai dengan karakteristik anak usia dini yang aktif, rasa ingin tahu yang tinggi, banyak bertanya, dan sering bereksplorasi dengan lingkungannya yang tercemin dalam kegiatan pembelajaran yang menyenangkan bagi anak.

Menurut Wiyani (2014.h.123) diartikan bahwa kemampuan sosialemosional sebagai perbuatan yang disertai dengan perasaan-perasaan tertentu yang melingkupi anak usia dini di saat berhubungan dengan orang lain. Perasaan yang dirasakan dan kemampuan yang dimiliki anak sangat berguna ketika anak memasuki lingkungan sekolah dan lingkungan masyarakat

Menurut Moeslichatoen (2004.h.137) Metode proyek merupakan salah satu cara pemberian pengalaman belajar dengan menghadapkan anak pada permasalahan dan persoalan sehari- hari yang harus di kerjakan secara berkelompok. Metode proyek merupakan cara pemecahan masalah yang melibatkan persoalan sehari-hari sehingga dapat memberikan pengalaman terhadap siswa. 
Dalam kemampuan sosial emosional salah satunya terdapat mampu berinteraksi dan bersosialisasi, mengenal perasaan, dan mengendalikan emosi yang tercantum pada Peraturan Menteri (Permen) No. 137 tahun 2014. Sebagaimana anak usia 5-6 tahun. Menerawang sebuah metode dalam hal ini adalah metode dapat dilakukan melalui sebuah penyelidikan terhadap sebuah tema. Metode proyek menurut Grant dalam Priansa (2017.h.207) metode proyek adalah pembelajaran secara konstruksi, komperhensif, berpusat pada peserta didik dan mengajak peserta didik untuk melakukan investigasi mendalam terhadap suatu topik. Metode proyek cara pembelajaran dalam melakukan investigasi terhadap permasalahan sehari-hari pada peserta didik dalam suatu topik atu tema secara konstruktif, komperhensif,dan berpusat pada peserta didik.

Metode proyek menurut Djamarah dan Aswan Zain (2014.h.83). Metode proyek atau unit merupakan cara penyajian pelajaran yang bertitik tolak dalam suatu masalah, kemudian di bahas dari berbagai segi yang berhubungan sehingga dapat dipecahkan secara keseluruhan dan bermakna. Metode proyek merupakan cara yang menggunakan titik tolak yang menyajikan permasalahan bermakna yang berhubungan sehingga dapat dipecahkan. Metode proyek menurut "Buku Panduan Pendidikan kurikulum 2013 PAUD” metode proyek merupakan suatu tugas yang terdiri atas rangkaian kegiatan yang diberikan oleh pendidik kepada anak, baik secara berkelompok maupun individu dengan menggunakan objek alam sekitar maupun kegiatan sehari-hari. Metode proyek merupakan rangkaian kegiatan yang diberikan guru terhadap anak dalam bentuk berkelompok maupun individu untuk mempelajari alam sekitar dan kegiatan sehari-hari

Dengan demikian, metode proyek dapat membantu meningkatkan kemampuan sosial emosional anak usia 5-6 tahun. Melalui metode proyek anak dapat mengembangkan pengetahuan mampu berinteraksi dan bersosialisasi dam 


\section{"Ceria"}

Jurnal Pendidikan Anak Usia Dini

ISSN 2301-9905

Volume 9, No.2, Januari 2019

Fakultas Keguruan dan Ilmu Pendidikan- Universitas Muhammadiyah Tangerang

ammpu mengenal perasaan serta mengendalikan emosi dan dapat memecahkan masalah sederhana dalam kehidupan sehari-hari.

\section{Metode}

Metode penelitian yang digunakan dalam penelitian ini adalah Penelitian Tindakan Kelas (PTK), dengan subjek penelitian yaitu anak kelompok B (usia 5-6 tahun) di TK Nurussyakirin Kec. Sindang Jaya Kab.Tangerang. Menurut kemmis dalam komaidi dan wijayati (2011:h 1) Penelitian Tindakan Kelas adalah penelitian tindakan yang dilakukan oleh peserta didik dalam situasi sosial untuk meningkatkan penalaran dan praktik pendidikan sosial. Dalam penelitian ini kolaborasi dilakukan antara peneliti dan guru kelas, dimana peneliti bertindak sebagai observer dan guru bertindak sebagai pelaksana tindakan. Dalam Penelitian Tindakan Kelas ini, tindakan yang dilakukan adalah meningkatkan kemampuan sosial emosional anak usia 5-6 tahun, dengan fokus pada aspekaspek anak dapat bekerja sama dengan teman sebaya, anak dapat melaksanakan tugas individu dan kelompok,anak dapat bermain dengan teman sebaya, anak dapat mengenal perasaan sendiri dan orang lain, dapat menunjukan rasa percaya, anak dapat mengendalikan emosi, sabar menunggu giliran, mematuhi peraturan, dan bertanggung jawab dalam mengerjakan tugas.

Desain penelitian yang digunakan adalah model Kemmis dan Taggart, yaitu dilakukan dalam tiga siklus dan tiga tindakan/pertemuan pada setiap siklusnya. Tahapan dalam penelitian ini adalah perencanaan, pelaksanaan, tindakan, pengamatan dan refleksi. Instrumen yang digunakan dalam penelitian ini yaitu berupa lembar penilaian berupa daftar observasi, catatan wawancara, catatan lapangan serta dokumentasi. Teknik analisis data yang digunakan adalah berupa data kuantitatif dan data kualitatif. 


\section{Hasil Dan Pembahasan}

Penelitian tindakan kelas di Tk.Nurussyakirin Sindang Jaya Kab.Tangerang. Peningkatan kemampuan sosial Emosional anak dalam penelitian ini dilakukan dengan metode proyek dalam tiga siklus, setiap siklus terdiri dari tiga pertemuan. Kemampuan sosial Emosional anak dapat diukur berdasarkan tiga indikator yaitu berinteraksi dan bersosialisasi, mengenal perasaan diri sendiri, dan mengendalikan emosi. Penerapan metode proyek dilakukan peneliti menggunakan alat dan bahan serta membahas tema yang berbeda pada setiap siklus. Pada siklus I tema yang dibahas adalah diri ku dengan sub tema panca indra. Alat dan bahan yang digunakan adalah gambar panca indera (mata), lembar kerja dan stik ice cream,origami, lem,piring ulang tahun dan foto anak.

Hasil pengamatan pada siklus I peneliti mengamati bahwa anak yang meningkat kemampuan sosial Emosionala nya ada 1 anak, berikut tabel peningkatan kemampuan sosial emosional dapat dilihat pada tabel hasil observasi di bawah

\section{Hasil observasi kemampuan sosialemosional siklus 1}

\begin{tabular}{|c|c|c|c|c|c|c|c|c|c|c|c|c|c|c|c|c|}
\hline \multirow[t]{2}{*}{ No } & \multirow[t]{2}{*}{ Nama anak } & \multicolumn{11}{|c|}{ Indikator } & & & \multirow{2}{*}{$\sum \mathbf{n}$} & \multirow[t]{2}{*}{ presentase } \\
\hline & & \multicolumn{2}{|r|}{1} & \multicolumn{2}{|c|}{ Rata } & \multicolumn{2}{|r|}{2} & \multicolumn{2}{|c|}{ Rata } & \multicolumn{3}{|c|}{3} & \multicolumn{2}{|c|}{ Zata } & & \\
\hline 1 & adn & 3 & 3 & 3 & 3 & 3 & 3 & 3 & 3 & 3 & 3 & 3 & 3 & 3 & 30 & 75 \\
\hline 2 & kah & 1 & 2 & 2 & 2 & 2 & 2 & 2 & 2 & 2 & 2 & 3 & 2 & 2 & 19 & 48 \\
\hline 2 & ran & 2 & 3 & 3 & 3 & 3 & 3 & 2 & 3 & 2 & 3 & 2 & 3 & 3 & 26 & 65 \\
\hline 4 & fdn & 1 & 2 & 3 & 2 & 2 & 2 & 2 & 2 & 2 & 2 & 2 & 2 & 2 & 20 & 50 \\
\hline 5 & abd & 2 & 2 & 2 & 2 & 2 & 2 & 2 & 2 & 2 & 2 & 2 & 2 & 2 & 20 & 50 \\
\hline 6 & ijl & 1 & 2 & 3 & 2 & 3 & 2 & 2 & 2 & 2 & 2 & 2 & 2 & 2 & 21 & 53 \\
\hline 7 & blqsi & 1 & 2 & 3 & 2 & 2 & 3 & 2 & 2 & 2 & 2 & 2 & 3 & 2 & 22 & 55 \\
\hline 8 & blqs & 2 & 3 & 3 & 3 & 2 & 2 & 3 & 2 & 3 & 3 & 2 & 3 & 3 & 26 & 65 \\
\hline 9 & ptri & 2 & 2 & 2 & 2 & 2 & 2 & 2 & 2 & 2 & 2 & 2 & 3 & 2 & 21 & 53 \\
\hline 10 & lul & 2 & 3 & 3 & 3 & 3 & 3 & 3 & 3 & 2 & 2 & 2 & 3 & 2 & 26 & 65 \\
\hline 11 & bil & 2 & 2 & 2 & 2 & 1 & 2 & 2 & 2 & 2 & 2 & 2 & 2 & 2 & 20 & 50 \\
\hline 12 & rub & 1 & 2 & 2 & 2 & 2 & 2 & 3 & 2 & 2 & 2 & 2 & 2 & 2 & 20 & 50 \\
\hline \multicolumn{13}{|c|}{ Jumlah } & & & 271 & 677,5 \\
\hline \multicolumn{13}{|c|}{ Rata-rata } & & & 23 & 56 \\
\hline
\end{tabular}




\section{"Ceria”}

Jurnal Pendidikan Anak Usia Dini

ISSN 2301-9905

Volume 9, No.2, Januari 2019

Fakultas Keguruan dan Ilmu Pendidikan- Universitas Muhammadiyah Tangerang

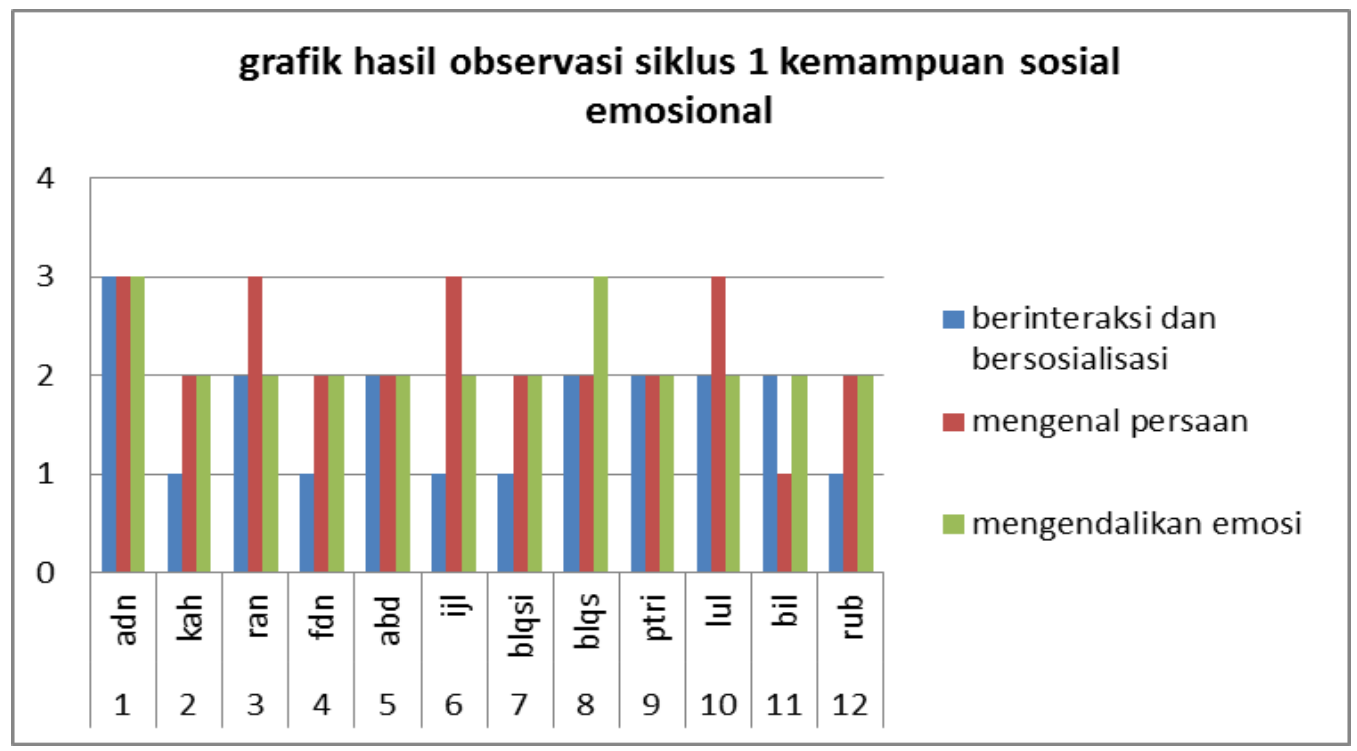

Berdasarkan hasil refleksi yang dilakukan di siklus 1 dari 12 siswa di kelas B1 yang telah mampu berkembang sesuai harapan baru 6 siswa yaitu,blqs, blqs i, ijl, ran,ptr dan lul sedang yang mulai berkembang 5 siswa yaitu kah,fdn, abd, bil dan rubi. Sedangkan yang mencapai indikator keberhasilan berkembang sangat baik 1 anak Dengan pencapain persentase $8 \%$ kegiatan yang dilakukan pada siklus 1 yaitu (1) membuat bingkaifoto, (2) membuat kolase gambar pakaian, dan (3) membuat bentuk gambar orang dari bentuk geometri.

Observasi dan hasil belajar anak pada siklus 1 sudah ada peningkatan agar mendapatkan hasil yang maksimal maka peneliti melanjutkan tindakan pada siklus 2 karena masih ada anak yang perlu arahan dan stimulasi.

\section{Hasil observasi siklus 2}

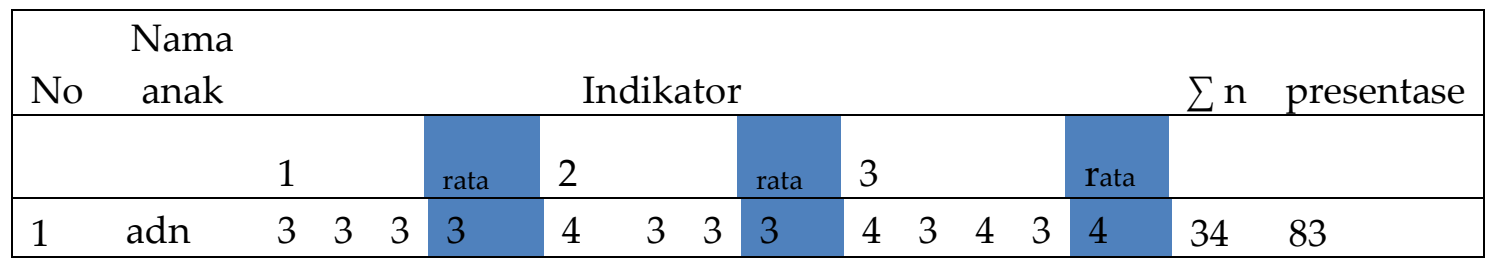




\begin{tabular}{|lllllllllllllllllll|}
\hline 2 & kah & 3 & 3 & 3 & 3 & 2 & 3 & 2 & 2 & 2 & 3 & 2 & 2 & 2 & 25 & 63 \\
\hline 3 & ran & 3 & 3 & 3 & 3 & 3 & 3 & 3 & 3 & 2 & 3 & 2 & 3 & 3 & 26 & 65 \\
\hline 4 & fdn & 3 & 2 & 2 & 2 & 3 & 2 & 2 & 2 & 3 & 3 & 2 & 3 & 3 & 25 & 63 \\
\hline 5 & abd & 2 & 3 & 2 & 2 & 2 & 2 & 2 & 2 & 3 & 2 & 2 & 3 & 3 & 23 & 58 \\
\hline 6 & ijl & 3 & 2 & 2 & 2 & 2 & 3 & 2 & 2 & 3 & 3 & 2 & 2 & 3 & 24 & 60 \\
\hline 7 & blqsi & 3 & 4 & 4 & 3 & 4 & 3 & 4 & 3 & 3 & 3 & 3 & 3 & 3 & 34 & 85 \\
\hline 8 & blqs & 4 & 3 & 4 & 3 & 4 & 4 & 3 & 3 & 3 & 4 & 3 & 3 & 3 & 35 & 88 \\
\hline 9 & ptri & 4 & 3 & 4 & 3 & 4 & 3 & 3 & 3 & 3 & 3 & 4 & 3 & 3 & 34 & 85 \\
\hline 10 & lul & 4 & 3 & 4 & 3 & 4 & 4 & 3 & 3 & 3 & 3 & 3 & 3 & 3 & 34 & 85 \\
\hline 11 & bil & 3 & 3 & 4 & 3 & 3 & 3 & 3 & 3 & 4 & 3 & 3 & 3 & 3 & 34 & 85 \\
\hline 12 & rub & 3 & 4 & 4 & 3 & 3 & 3 & 3 & 3 & 3 & 3 & 4 & 3 & 3 & 32 & 80 \\
\hline Jumlah & & & & & & & & & & & & & & 359 & 897,5 \\
\hline \multicolumn{2}{l}{ Rata-rata } & & & & & & & & & & & & & & & & &
\end{tabular}

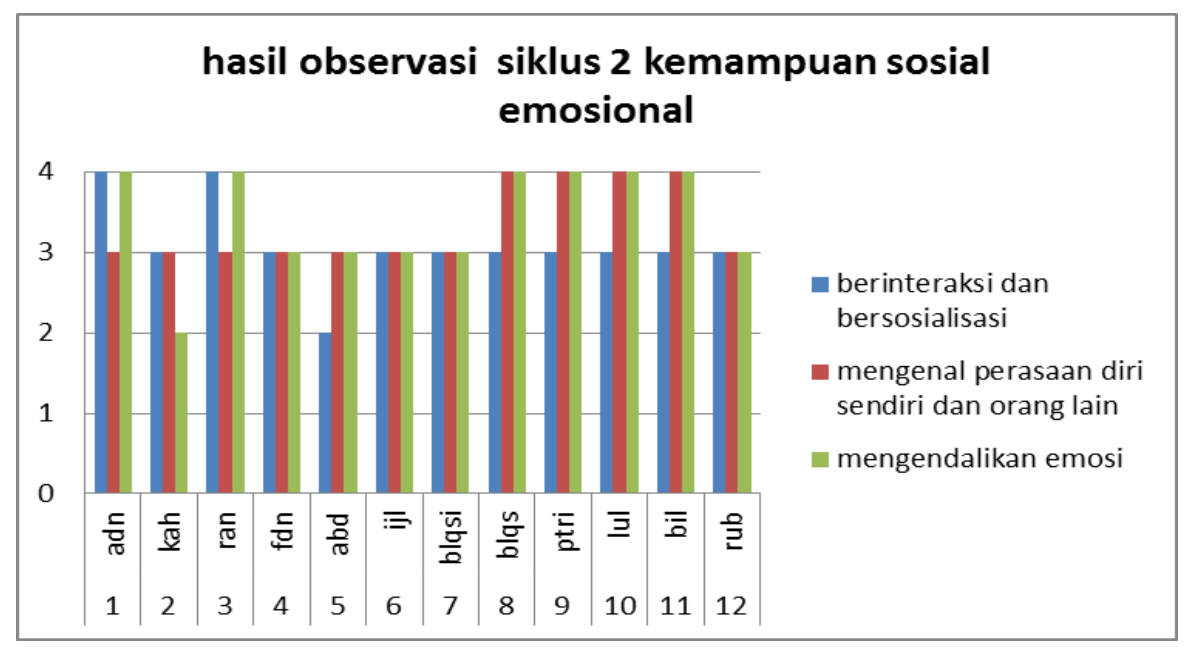

Hasil pengamatan yang dilakukan di siklus II dari 12 siswa di kelas B1 yang telah mampu berkembang sangat baik hanya 6 siswa yaitu adn, blqs i, bil, lul, rub, dan blqs sedang yang berkembang sesuai harapan ada kah, fdn, abd, ijl, ptr,dan ran Dengan hasil persentasi $50 \%$.

Berdasarkan refleksi yang dilakukan pada siklus II peneliti melakukan perbaikan Dari hasil yang di dapat siswa belum mencapai indikator yang maksimal maka peneliti melakukan tindakan selanjutnya pada siklus III dengan kegiatan proyek, (1) membuat es buah, (2) memnbuat toge, (3) membuat sate sayuran kentang dan wortel.berikut hasil peningkatan pada siklu III. 


\section{"Ceria”}

Jurnal Pendidikan Anak Usia Dini

ISSN 2301-9905

Volume 9, No.2, Januari 2019

Fakultas Keguruan dan Ilmu Pendidikan- Universitas Muhammadiyah Tangerang

Observasi dan hasil belajar anak pada siklus II ,sudah ada peningkatan terutama pada indikator mengenal emosi, berinteraksi dan bersosialisasi namun mengenal persaan diri sendiri dan orang lain masih perlu arahan dan bimbingan. 
Hasil observasi kemampuan sosial emosional siklus 3

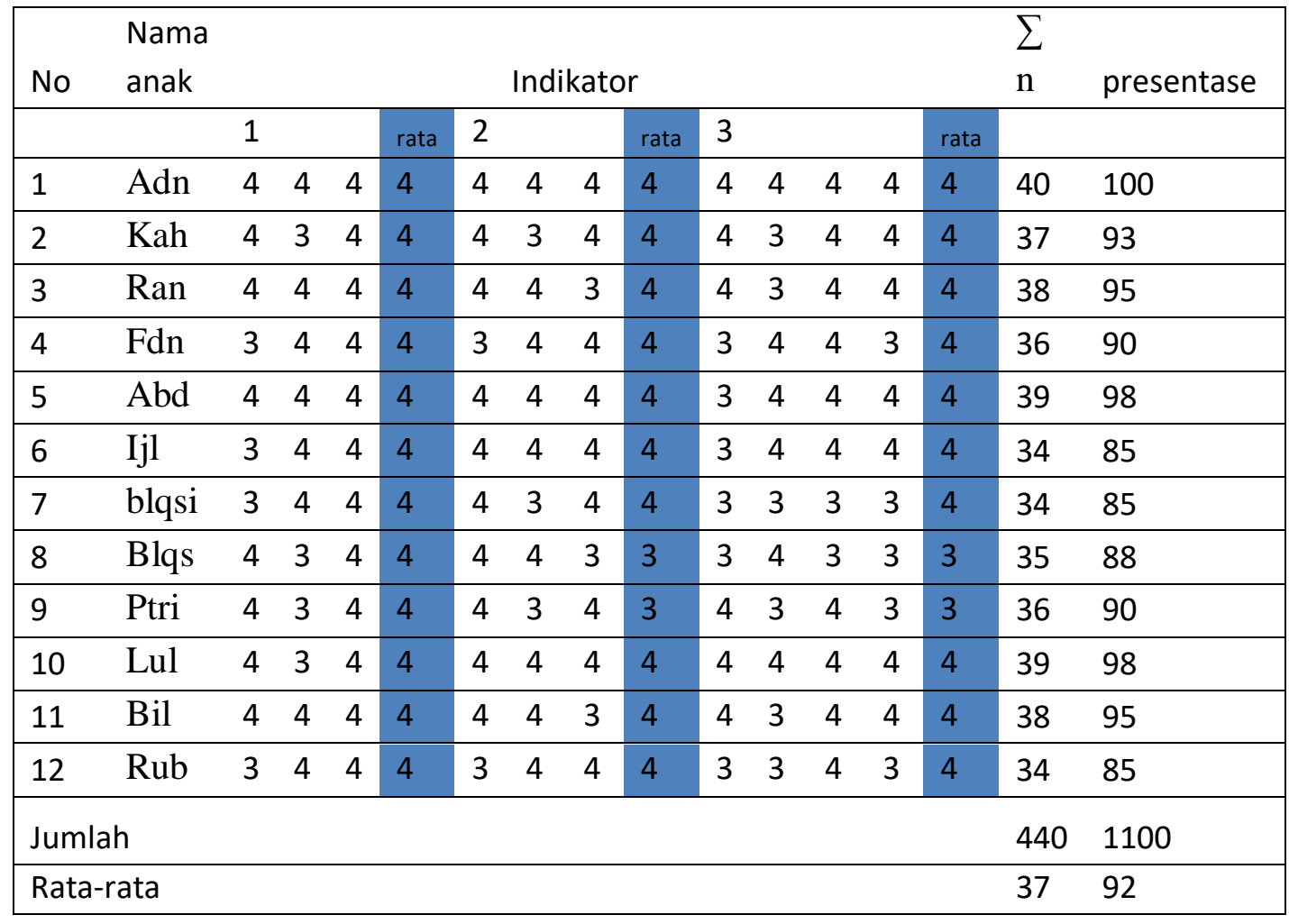

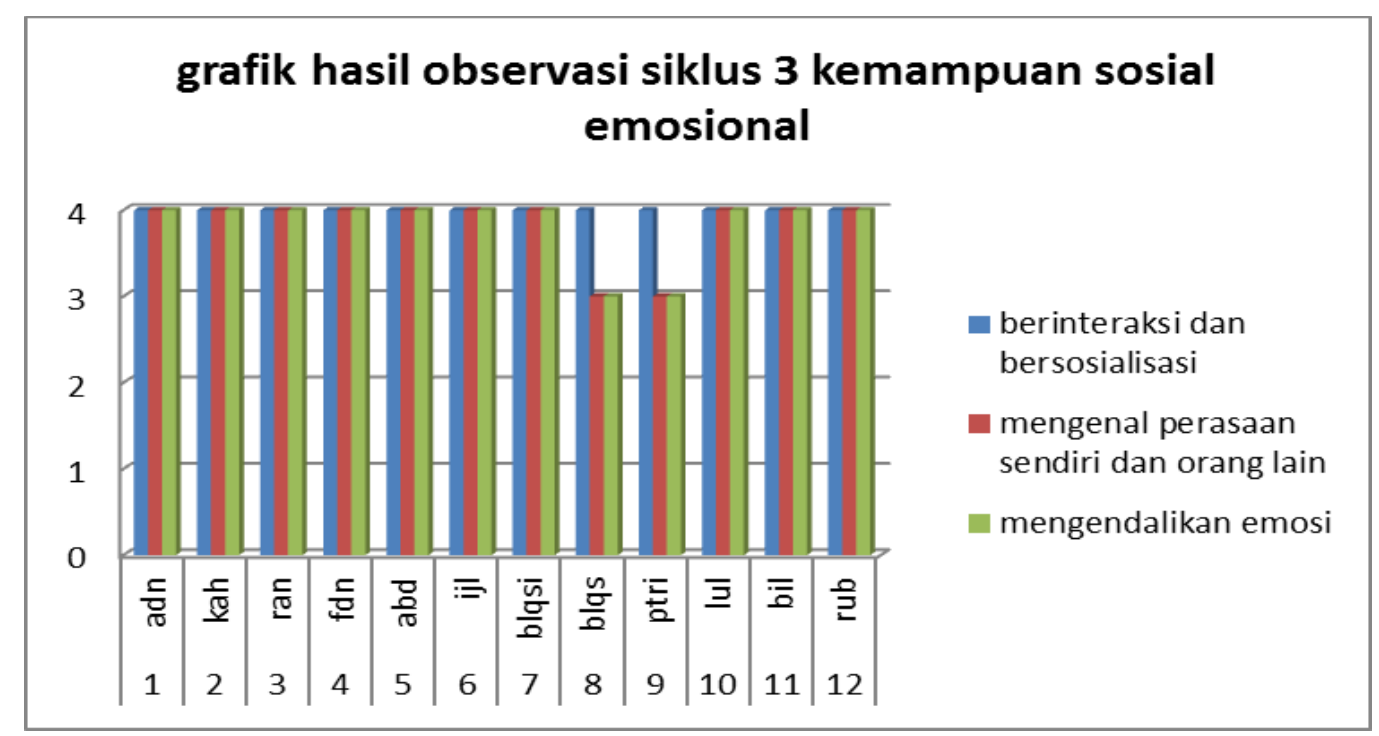

berdasarkan hasil pengamatan yang dilakukan pada siklus III alhamdulilah dari kegiatan proyek yang dilakukan untuk meningkatkan kemampuan sosial emosional di TK.Nurussyakirin ternyata dari keseluruhan 12 siswa sudah mencapai kriteria indikator keberhasilan berkembang sangat baik 


\section{"Ceria"}

Jurnal Pendidikan Anak Usia Dini

ISSN 2301-9905

Volume 9, No.2, Januari 2019

Fakultas Keguruan dan Ilmu Pendidikan- Universitas Muhammadiyah Tangerang

dengan persentase $100 \%$. Dengan hasil yang di dapat pada siklus III maksimal, peneliti menghentikan tindakan sampai siklus III dengan hasil persentase $100 \%$.

Berdasarkan pemaparan diatas hasil dari data kemampuan sosial emosional anak dapat diketahui bahwa melalui metode proyek dapat meningkatkan kemampuan sosial emosional.1) berinteraksi dan bersosialisasi (a) anak dapat bekerja sama dengan teman sebaya,(b) dapat mealakukan tugas individu dan kelompok (c) anak dapat bemain dengan teman sebaya. 2) mengenal perasaan diri sendiri dan orang lain, (a) anak dapat mengenal perasaan senang, sedih, marah, kecewa (b) anak dapat mengalami perasaan yang dialami orang lain (c) anak dapat menunjukan rasa percaya diri. 3) mengendalikan emosi (a) dapat menegandalikan emosi secara wajar, (b) dapat sabar menunggu giliran ketika mencuci tangan (c) dapat mematuhi peraturan (d) dapat bertanggung jawab dalam mengerjakan tugas.

Hal ini sesuai dengan Penelitian yang dilakukan mahasiswa RIZKI AYUDIA Jurusan : Pendidikan Guru Raudhatul Athfal Fakultas tarbiyah dan keguruan intitut agama islam negeri raden intan lampung 1438 H / 2017 M yang berjudul " mengembangkan sosial emosional anak melalui metode bercerita di kelompok B.1 RA AL-ULYA bandar lampung " berdasarkan pemaparan diatas senada dengan penelitian yang dilakukan Meylia Herli Susanti yang berjudul “ Upaya Meningkatkan Kecerdasan Sosial Emosional Melalui Metode Bermain Peran pada anak Taman Belia Candi Semarang Tahun 2012/2013" penelitian ini mempunyai tujuan yang sama yaitu untuk mengembangkan dan meningkatkan kemampuan sosial emosional anak.

\section{Kesimpulan}

Berdasarkan hasil penelitian yang dilakukan berkenaan dengan upaya meningkatkan kemampuan sosial Emosional melalui metode proyek usia 5-6 
tahun di Tk.Nurussyakirin Sindang Jaya Kab.Tangerang. Dapat di ambil kesimpulan yaitu: (1) dengan menggunakan metode proyek dapat meningkatkan kemampuan sosial emosional di Tk.Nurussyakirin Sindang Jaya Kab. Tangerang, hal ini dapat dilihat pada peningkatan kemampuan sosial emosional dari kondisi awal $42 \%$, pada kondisi awal ke siklus 1 meningkat sebesar $56 \%$, pada siklus 1 ke siklus II meningkat sebesar $75 \%$, dan pada siklus II ke siklus III meningkat sebesar $100 \%$. (2) berdasarkan kesimpulan diatas bahwa metode proyek dapat di terapkan dalam kegiatan pembelajaran, dan sebagai guru mampu menggunakan berbagai metode dalam kegiatan belajar mengajar (KBM) salah satunya metode proyek serta orangtua harus mengerti dan memahami gaya belajar dan karakteristik anak. untuk mengembangkan potensi anak dalam tahapan perkembangan anak dengan memberikan kesempatan kepada anak untuk mengasah dan meningkatkan kreatifitas atau kemampuan salah satunya kemampuan sosial emosional agar lebih maksimal.

\section{Daftar acuan}

Djamarah, dan Azwan Z. (2014).Strategi Belajar Mengajar. Jakarta : PT. Rineka Cipta.

Meylia Herly susanti.(2012 / 2013) Meningkatkan kecerdasan sosial emosional anak bermain peran (pdf downlod )jurnal .

Komaidi, Wahyu,W. (2011).Panduan Lengkap PTK Penelitian Tindakan Kelas:Teori, Praktik dan contoh PTK.Yogyakarta:Sabda Media

Mashar,Riana, (2011). Emosi Anak Usia Dini dan Strategi Pengembangannya. Jakarta: Kencana Prenada Media Group.

Moeslichatoen. (2004). Metode Pengajaran Di Taman Kanak-Kanak. Jakarta: PT.Rineka Cipta.

Permendikbud (2014.) peraturan menteri pendidikan dan kebudayaan republik indonesia.Standar Tingkat Pencapaian Perkembangan Sosialemosional 137. Anak Usia 5-6 Tahun. 


\section{"Ceria”}

Jurnal Pendidikan Anak Usia Dini

ISSN 2301-9905

Volume 9, No.2, Januari 2019

Fakultas Keguruan dan Ilmu Pendidikan- Universitas Muhammadiyah Tangerang

Priansa, doni, J.(2017).Pengembangan Strategi dan Model Pembelajaran.Bandung: PT.Rineka Cipta

Ayudia, Rizki. (2017).mengembangkan sosialemosional anak melalui metode bercerita di kelompok b.1 RA.AL-ULYA Bandar lampung.FTKIA Negeri Raden Intan Lampung.(JURNAL)

Wiyani, Ardy Novan. (2014). Mengelola \& Mengembangkan Kecerdasan Sosial\&Emosi Remaja.Bandung:Rosda Karya

Susanto,Ahmad. (2011).Perkembangan Anak Usia Dini:Pengantar Dalam Berbagai Aspeknya: jakarta.kencana prenadamedia 